\title{
Selective liquid-phase oxidation of allyl alcohol to glycidol over MWW type titanosilicalite
}

\author{
Anna Fajdek • Agnieszka Wróblewska • \\ Eugeniusz Milchert
}

Received: 4 February 2011/Accepted: 23 March 2011/Published online: 7 April 2011

(C) The Author(s) 2011. This article is published with open access at Springerlink.com

\begin{abstract}
The results of the epoxidation of allyl alcohol with $30 \%$ hydrogen peroxide over the Ti-MWW catalyst have been presented. The studies were carried out under atmospheric pressure and in the presence of methanol as a solvent. The influence of the following technological parameters on the course of epoxidation was examined: temperature $\left(20-60{ }^{\circ} \mathrm{C}\right)$, the molar ratio of $\mathrm{AA} / \mathrm{H}_{2} \mathrm{O}_{2}(1: 1-5: 1)$, methanol concentration $(5-90 \mathrm{wt} \%)$, catalyst content $(0-5.0 \mathrm{wt} \%)$, reaction time (5-300 $\mathrm{min})$ and intensity of stirring (0-500 rpm).
\end{abstract}

Keywords Glycidol · Ti-MWW catalyst - Liquid-phase epoxidation · Hydrogen peroxide

\section{Introduction}

Zeolites are crystalline aluminosilicates with 133 known frameworks. Their pores are highly monodisperse and have a fixed directionality within the crystal. The pores in these systems often have a character of cages and connection tubes. The uniformity of the channels in the zeolitic system means that they are extremely selective adsorbents for small molecules of particular geometries and sizes and so make highly selective catalytic supports and adsorbents. Due to the pore sizes comparable to the molecular dimensions, zeolites are also called molecular sieves [1].

MWW (MCM-22) is a molecular sieve which crystallizes as thin sheets or plates and has a unique and unusual crystal structure. The thin crystals exhibit a hexagonal morphology, with the unit cell $c$-axis perpendicular to the plate surface. The

\footnotetext{
A. Fajdek · A. Wróblewska $(\bowtie) \cdot$ E. Milchert

Institute of Organic Chemical Technology, West Pomeranian University of Technology Szczecin, Pułaskiego 10, 70-322 Szczecin, Poland

e-mail: agnieszka.wroblewska@zut.edu.pl
} 
framework topology is composed of two independent pore systems. One of these pore systems is defined by two-dimensional sinusoidal channels, which maintain an effective 10-ring diameter throughout the entire structure. The other system is composed of large supercages whose inner free diameter $7.1 \AA$, is defined by 12-rings and whose inner height is $18.2 \AA$ [1].

Ti-MWW is not only more active than TS-1 and Ti-Beta in the liquid-phase epoxidation of small, linear alkenes with hydrogen peroxide, but is also highly selective for the formation of epoxides [2]. In addition, this material also exhibits a unique feature of selective epoxidation of the trans isomer in the oxidation of cisand trans-2-hexenes [3,4]. Actually, a potential advantage of the MWW structure is expected from its interlayer supercages and side pockets, which could be very useful for catalyzing the reactions involving bulky molecules (for this reactions now are also effectively used mesoporous titanium silicalite catalysts, for example Ti-MCM-41, Ti-MCM-48 or Ti-SBA-15). The retention of lamellar-like structure with expanded layer spacing after calcinations would be an alternative way to create the open reaction space in the disproportionation of toluene and in the alkylation of benzene [5]. Ti-MWW catalyzes the epoxidation of bis(allyl) ether (BAE) to allylglycidyl ether (AGE) and bis(glycidyl) ether (BGE) with aqueous hydrogen peroxide [6]. Ti-MWW is capable of catalyzing the liquid-phase ammoximation of cyclohexanone to oxime at a conversion and selectivity $>99 \%$ in the presence of water under the optimum conditions, and proves to be a promising catalyst for oxime synthesis [7].

The epoxides belong to a group of ethers; however, their properties are different from those of the typical ethers, due to the internal strain in the heterocyclic ring [8]. The major product of liquid-phase oxidation of allyl alcohol-glycidol is an important monomer and semi-product in the synthesis of surface-active agents. These agents are the components of cosmetic preparations for skin moisturizing and purifying, hair shampoo, toothpaste, laundering detergents and disinfectants [9]. The surface-active agents are also used as the food emulsifiers in the production of margarine, ice-cream, and vegetable butter $[10,11]$. Other applications of glycidol include plasticizers, fabric dyes, photochemical compounds, rubbers, varnishes and plastics. One of the most important applications of glycidol is the synthesis of antiviral and analgesic drugs. The active compounds fighting HIV constitute especially component group of antivirial dugs. With the use of glycidol, the active compounds fighting HIV are obtained, which comprise the equivalents of natural compounds contained in fungus, as well as new derivatives of nucleotides fighting HIV and other viruses [11].

\section{Experimental}

Preparation of Ti-MWW catalyst and its characteristics

The Ti-MWW catalyst was prepared according to the method described by Wu et al. [12]. The detailed characteristic of the catalyst was presented in our previous work [13]. 
Epoxidation of allyl alcohol

In the process of allyl alcohol epoxidation, the following reactants were used: allyl alcohol (AA, $98 \mathrm{wt} \%$, Fluka), the Ti-MWW titanium silicalite catalyst (prepared in the Institute of Organic Chemical Technology, West Pomeranian University of Technology, Szczecin), hydrogen peroxide (30 wt \% water solution) and methanol (analytical grade both were from P.O.Ch. Gliwice, Poland).

The epoxidation was performed under atmospheric pressure in a glass reactor with a magnetic stirrer. The determined amounts of reactants were introduced into the reactor in the following sequence: the Ti-MWW catalyst, allyl alcohol, methanol (solvent) and a $30 \mathrm{wt} \%$ hydrogen peroxide was added at the reaction temperature. The process was carried out for a specified period of time. After the process was completed, a postreaction mixture was weighed and analyzed. The range of changes of the examined technological parameters was as follows: the temperature of $20-60{ }^{\circ} \mathrm{C}$, the molar ratio of $\mathrm{AA} / \mathrm{H}_{2} \mathrm{O}_{2}$ 1:1-5:1, solvent concentration (methanol) of 5-90 wt\%, catalyst content of 0-5.0 wt\%, reaction time of 5-300 min and the intensity of stirring 0-500 rpm.

In order to calculate the mass balance for the syntheses performed, the post-reaction mixtures were analyzed in the following way: unreacted hydrogen peroxide was determined by means of the iodometric method, glycerol formed in the process was determined by means of potentiometric method. The remaining products and the unreacted organic substrate were analyzed by gas chromatography. The chromatographic analysis was performed on the FOCUS apparatus with a flame-ionization detector (FID) fitted with Quadrex capillary columns $(30 \mathrm{~m} \times 250 \mu \mathrm{m} \times 0.25 \mu \mathrm{m})$ filled with methyl-phenyl-siloxanes. The parameters of chromatographic separation were as follows: the pressure of helium $50 \mathrm{kPa}$, sensitivity 10 , the temperature of the sample chamber $150{ }^{\circ} \mathrm{C}$, the detector temperature $250{ }^{\circ} \mathrm{C}$, the temperature of the thermostat was increased according to the following program: isothermally at $50{ }^{\circ} \mathrm{C}$ for $3 \mathrm{~min}$, an increase to $250{ }^{\circ} \mathrm{C}$ at the rate of $10{ }^{\circ} \mathrm{C} / \mathrm{min}$, isothermally at $250{ }^{\circ} \mathrm{C}$ for $5 \mathrm{~min}$, cooling to $60{ }^{\circ} \mathrm{C}$. After the calculation of mass balance for each of the syntheses, the main functions describing the process were determined: the selectivity of the transformation to glycidol and by-products (glycerol, bis(allyl) ether, allylglycidyl ether, acrolein, 2-allyloxy-1,2-propanediol) in relation to the allyl alcohol consumed, the conversion of allyl alcohol, the selectivity of transformation to organic compounds in relation to hydrogen peroxide consumed. The magnitudes were calculated in the following way:

$$
\begin{gathered}
S_{\frac{\text { glc }}{\mathrm{AA}}}=\frac{\text { amount of moles of glycidol }(\text { or by }- \text { product })}{\text { amount of moles of allyl alcohol consumed }} \times 100[\mathrm{~mol} \%] \\
C_{\mathrm{AA}}=\frac{\text { amount of moles of allyl alcohol consumed }}{\text { amount of moles of allyl alcohol introduced into reactor }} \times 100[\mathrm{~mol} \%] \\
S_{\frac{\mathrm{H}}{\mathrm{H}_{2} \mathrm{O}_{2}}}=\frac{\text { amount of moles of formed organic compounds }}{\text { amount of moles of } \mathrm{H}_{2} \mathrm{O}_{2} \text { consumed }} \times 100[\mathrm{~mol} \%]
\end{gathered}
$$

Glycidol, which undergoes a partial hydration to glycerol under the reaction conditions, is the main product of the epoxidation of allyl alcohol. Depending on the conditions of epoxidation, a small amount of ethers (bis(allyl) and allyl-glycidyl) 


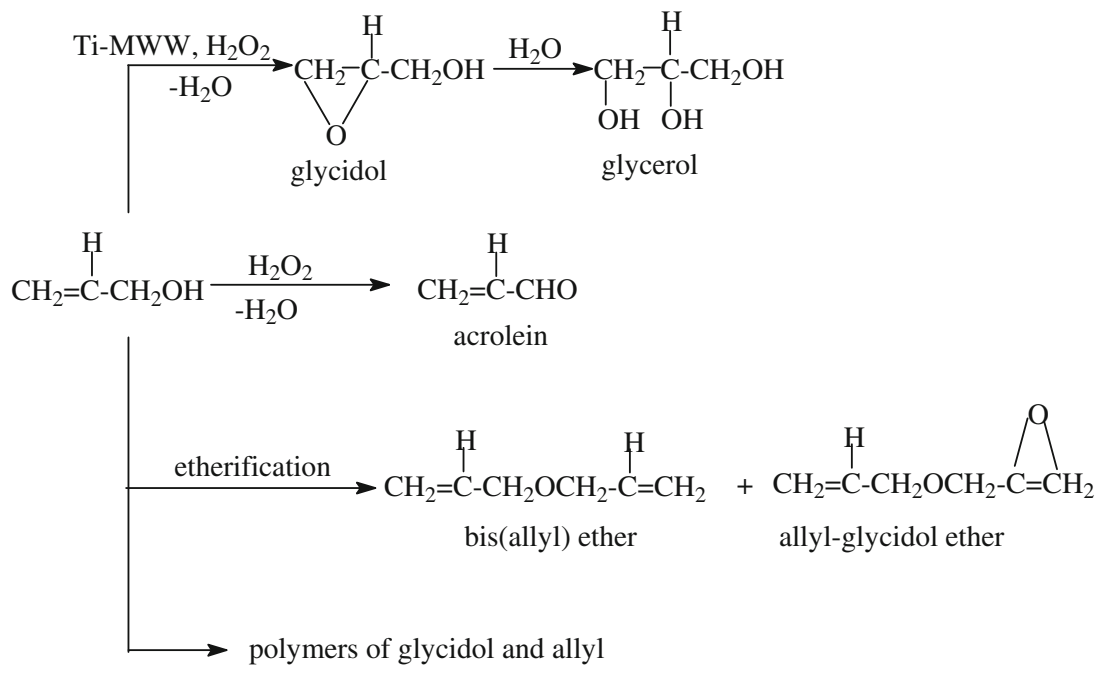

Fig. 1 Major and by-products of the epoxidation of allyl alcohol with $30 \%$ hydrogen peroxide over the Ti-MWW titanium silicalite catalyst

are formed in the process. In higher temperature the polymerization occurs to a small extent (Fig. 1):

\section{Results and discussion}

The influence of temperature

The influence of the temperature in the range of $20-60{ }^{\circ} \mathrm{C}$ during the course of allyl alcohol epoxidation over Ti-MWW catalyst was studied (Fig. 2). The initial parameters of the epoxidation in the stage were as follows: the molar ratio AA/ $\mathrm{H}_{2} \mathrm{O}_{2}=1: 1$, methanol concentration (solvent) $40 \mathrm{wt} \%$, Ti-MWW concentration $2 \mathrm{wt} \%$, the reaction time $3 \mathrm{~h}$ and the intensity of stirring $500 \mathrm{rpm}$.

As the results show, an increase in the temperature from 20 to $60{ }^{\circ} \mathrm{C}$ does not have a significant impact on the selectivity of transformation to glycidol in relation to allyl alcohol consumed. The values of this function are at the level of about $20 \mathrm{~mol} \%$. The analysis of the composition indicates a slight increase in the part of glycerol, which is a consequence of hydrolysis of the epoxy ring in glycidol. The etherification products do not change, for example: allyl-glycidyl and bis(allyl) ether (Table 1).

At the time of the reaction, the first part of the hydrogen peroxide transforms into organic compounds and the second part of it decomposes ineffectively to oxygen and water. For safety reasons, hydrogen peroxide should be decomposed before the stage of product separation by fractional distillation. Owing to this, the possibility of violent decomposition of $\mathrm{H}_{2} \mathrm{O}_{2}$ and explosion is avoided. It is beneficial that the conversion of allyl alcohol should be the highest possible with simultaneously high selectivity of transformation to organic compounds in relation to hydrogen peroxide 


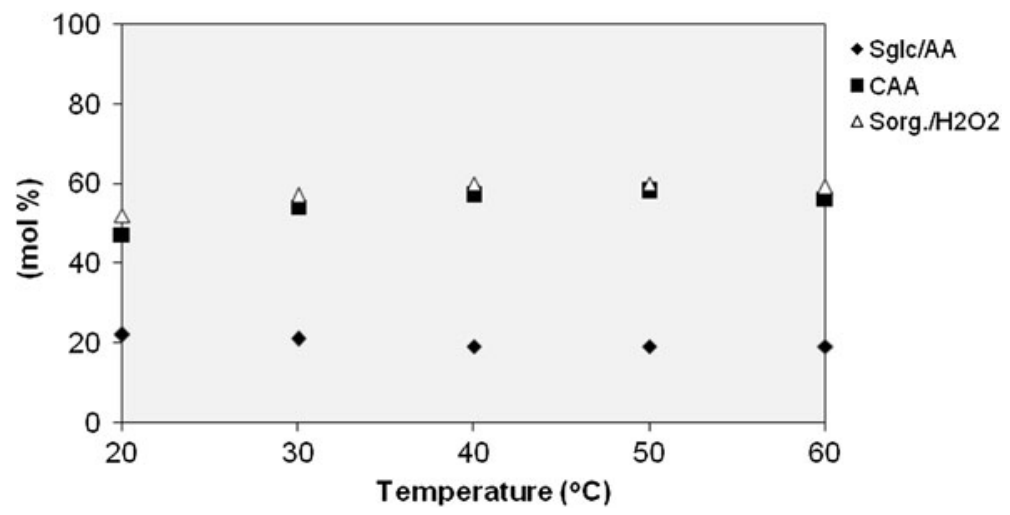

Fig. 2 The influence of temperature on the allyl alcohol epoxidation over Ti-MWW catalyst; AA/ $\mathrm{H}_{2} \mathrm{O}_{2}=1: 1$ molar ratio, methanol concentration $40 \mathrm{wt} \%$, Ti-MWW concentration $2 \mathrm{wt} \%$, reaction time $3 \mathrm{~h}$, intensity of stirring $500 \mathrm{rpm}$

Table 1 The influence of temperature on the selectivity of transformation to by-products in the epoxidation of allyl alcohol over Ti-MWW catalyst

\begin{tabular}{|c|c|c|c|c|c|}
\hline $\begin{array}{l}\text { Temperature } \\
\left({ }^{\circ} \mathrm{C}\right)\end{array}$ & $\begin{array}{l}\text { Glycerol } \\
\text { (GLYC) } \\
S_{\text {Glyc/AA }} \\
(\mathrm{mol} \%)\end{array}$ & $\begin{array}{l}\text { Bis(allyl) ether } \\
\text { (EBA) } \\
S_{\mathrm{EBA} / \mathrm{AA}} \\
(\mathrm{mol} \%)\end{array}$ & $\begin{array}{l}\text { Allyl-glycidyl } \\
\text { ether (EAG) } \\
S_{\text {EAG/AA }}(\mathrm{mol} \%)\end{array}$ & $\begin{array}{l}\text { Acrolein } \\
\text { (ACR) } \\
S_{\mathrm{ACR} / \mathrm{AA}} \\
(\mathrm{mol} \%)\end{array}$ & $\begin{array}{l}\text { 3-Allyloxy-1,2- } \\
\text { propanediol (3A2PD) } \\
S_{3 \mathrm{~A} 12 \mathrm{PD} / \mathrm{AA}}(\mathrm{mol} \%)\end{array}$ \\
\hline 20 & 62 & 6 & 5 & 0 & 5 \\
\hline 30 & 65 & 4 & 5 & 0 & 5 \\
\hline 40 & 67 & 4 & 5 & 0 & 5 \\
\hline 50 & 68 & 4 & 5 & 0 & 4 \\
\hline 60 & 67 & 4 & 5 & 1 & 4 \\
\hline
\end{tabular}

consumed. The selectivity of transformation to organic compounds in relation to hydrogen peroxide consumed changes insignificantly in the temperature range studied from $52 \mathrm{~mol} \%$ at $20{ }^{\circ} \mathrm{C}$ to $58 \mathrm{~mol} \%$ at $60{ }^{\circ} \mathrm{C}$. It is the result of the lower rate of the amount of organic compounds.

The conversion of hydrogen peroxide presented in this study is the sum of effective conversion of hydrogen peroxide (to organic compounds) and ineffective conversion of hydrogen peroxide which is connected with decomposition of hydrogen peroxide. With the increase of the temperature from 20 to $60{ }^{\circ} \mathrm{C}$, the increase of conversion of hydrogen peroxide is slow. It is possible that unreacted hydrogen peroxide is retained in the zeolite pores. This hydrogen peroxide is not determined by iodometric titration as unreacted hydrogen peroxide but is taken into consideration in the calculation of the total conversion of hydrogen peroxide, which remains very high. In the range of $20-40{ }^{\circ} \mathrm{C}$, the allyl alcohol conversion slightly increases from 48 to $56 \mathrm{~mol} \%$. The latter observation shows that the allyl alcohol conversion is practically constants with the increase of temperature. 
Hence, the optimum temperature of epoxidation is $20^{\circ} \mathrm{C}$ at which the selectivity of the transformation to glycidol in relation to allyl alcohol consumed at this temperature and the $\mathrm{H}_{2} \mathrm{O}_{2}$ conversion are high. However, it should be noted that the conversion of allyl alcohol and the selectivity of transformation to organic compounds in relation to $\mathrm{H}_{2} \mathrm{O}_{2}$ consumed are lower.

The influence of molar ratio

The influence of the molar ratio of $\mathrm{AA} / \mathrm{H}_{2} \mathrm{O}_{2}$ on the course of epoxidation was examined in the range from $1: 1$ to $5: 1$ and at the temperature of $20{ }^{\circ} \mathrm{C}$, while the other starting parameters were unchanged. The results from this investigation are presented in Fig. 3 and Table 2.

On the basis of Fig. 3, it can be concluded that the increasing molar ratio of AA/ $\mathrm{H}_{2} \mathrm{O}_{2}$ affects the selectivity to glycidol in relation to allyl alcohol. With the lower molar ratios (1:1) the value of this function amounts to about $22 \mathrm{~mol} \%$. As the molar ratio of $\mathrm{AA} / \mathrm{H}_{2} \mathrm{O}_{2}$ increases within the range of $2: 1-5: 1$ the selectivity to glycidol takes values at the level of $41 \mathrm{~mol} \%$.

As a result of appropriately high and increasing concentration of allyl alcohol in the reaction mixture, the access of water molecule to the glycidol molecule becomes more difficult and the hydrolysis of the epoxy ring proceeds more slowly. The hydrolysis has the main role in lowering the selectivity of transformation of allyl alcohol to glycidol because of high rate of reaction. However, conducting of the operation with such high excess of organic raw material $\left(\mathrm{AA} / \mathrm{H}_{2} \mathrm{O}_{2}=5: 1\right)$ is not beneficial due to expenditure of energy associated with the subsequent recovery and recycling of unreacted of allyl alcohol to the process. The conversion of allyl alcohol decreases with the increase of the molar ratio of $\mathrm{AA} / \mathrm{H}_{2} \mathrm{O}_{2}$ from $47 \mathrm{~mol} \%$ (the molar ratio of $\mathrm{AA} / \mathrm{H}_{2} \mathrm{O}_{2}=1: 1$ ) to $13 \mathrm{~mol} \%$ (the molar ratio of $\mathrm{AA} / \mathrm{H}_{2} \mathrm{O}_{2}=5: 1$ ). It confirms that the side reactions associated with the conversion of allyl alcohol, etherification type do not proceed more intensively. The selectivity of transformation to organic compounds in relation to hydrogen peroxide consumed increases from about 52-76 mol\%.

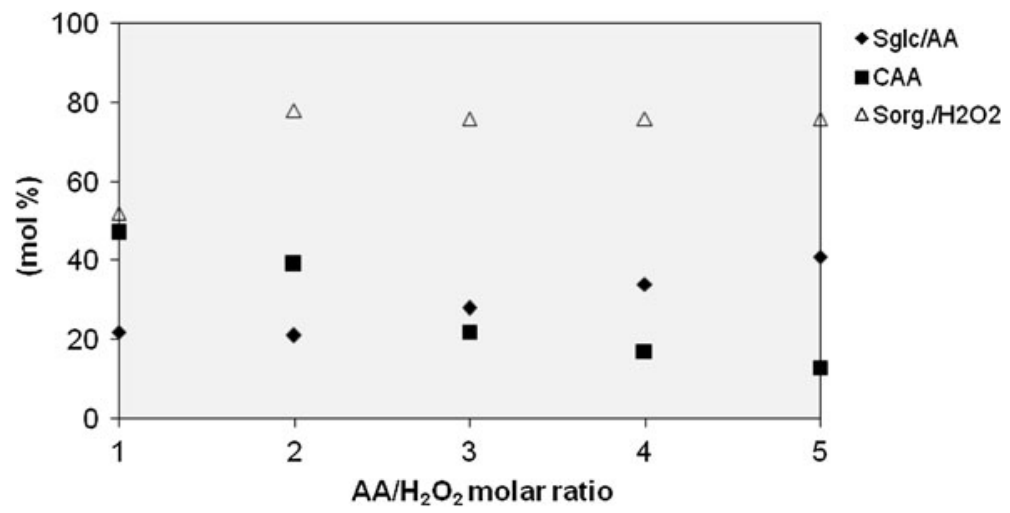

Fig. 3 The influence of the $\mathrm{AA} / \mathrm{H}_{2} \mathrm{O}_{2}$ molar ratio on the allyl alcohol epoxidation over Ti-MWW catalyst; temperature $20{ }^{\circ} \mathrm{C}$, methanol concentration $40 \mathrm{wt} \%$, Ti-MWW concentration $2 \mathrm{wt} \%$, reaction time $3 \mathrm{~h}$, intensity of stirring $500 \mathrm{rpm}$ 
Table 2 The influence of the $\mathrm{AA} / \mathrm{H}_{2} \mathrm{O}_{2}$ molar ratio on the selectivity of transformation to by-products in the epoxidation of allyl alcohol over Ti-MWW catalyst

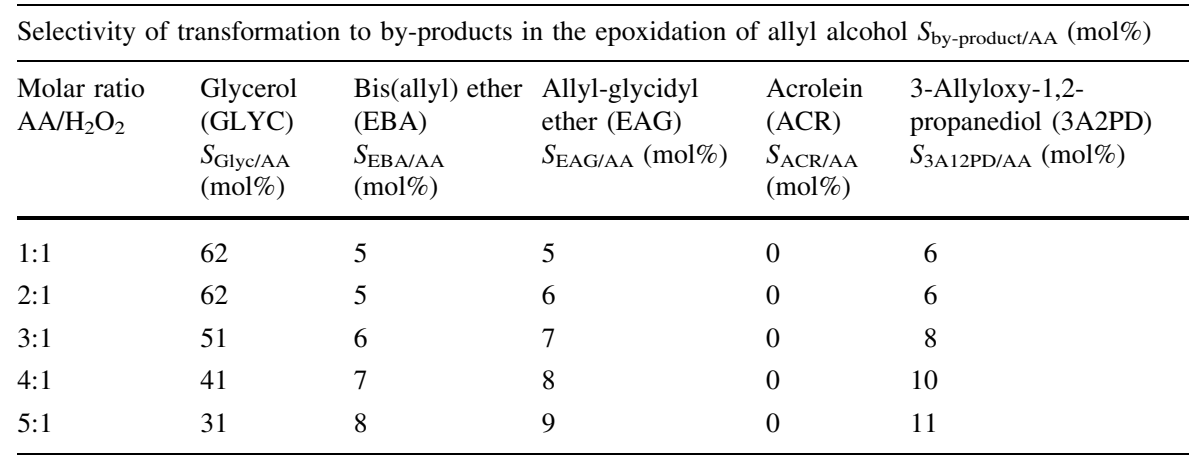

Thus, the molar ratio of $\mathrm{AA} / \mathrm{H}_{2} \mathrm{O}_{2}=1: 1$ is the optimal in the process of epoxidation. At this molar ratio, the selectivity of transformation to glycidol in relation to allyl alcohol amounts to $22 \mathrm{~mol} \%$, the selectivity of transformation to organic compounds in relation to hydrogen peroxide consumed equals $52 \mathrm{~mol} \%$, the conversion of allyl alcohol is $47 \mathrm{~mol} \%$ and the conversion of hydrogen peroxide is $94 \mathrm{~mol} \%$. The experiments at the molar ratios of $\mathrm{AA} / \mathrm{H}_{2} \mathrm{O}_{2}<1$ were not conducted, because according to the literature data [14], the excess of $\mathrm{H}_{2} \mathrm{O}_{2}$ in the post-reaction solution leached titanium from the structure of the catalyst, which changes the conditions of the process and decreases the selectivity of transformation. The second undesired phenomenon is an ineffective decomposition of $\mathrm{H}_{2} \mathrm{O}_{2}$.

The influence of solvent concentration

The effect of methanol concentration on the course of the epoxidation reaction was studied in the range of 5-90 wt\%, at the temperature of $20{ }^{\circ} \mathrm{C}$ and at the molar ratio of $\mathrm{AA} / \mathrm{H}_{2} \mathrm{O}_{2}=1: 1$ (Fig. 4 and Table 3). Other starting parameters were unchanged.

Analyzing the influence of the solvent concentration-methanol on the selectivity of transformation to glycidol it was concluded that the value of this function increases with the increase of the methanol concentration. The function reaches the highest value- $68 \mathrm{~mol} \%$ for the methanol concentration of $90 \mathrm{wt} \%$.

The largest increase of the conversion of allyl alcohol occurs in the range of the methanol concentration of 50-90 wt \%. At the lowest methanol concentration (5 wt $\%$ ) the conversion of allyl alcohol is equal to $65 \mathrm{~mol} \%$ and at the highest methanol concentration $(90 \mathrm{wt} \%)$ it achieves $85 \mathrm{~mol} \%$. The selectivity of transformation to organic compounds increases with the increase of the methanol concentration and rises to $77 \mathrm{~mol} \%$ ( $80 \mathrm{wt} \%$ of solvent). With this solvent concentration, the selectivity of transformation to glycidol in relation to allyl alcohol consumed reaches to $42 \mathrm{~mol} \%$, the conversion of allyl alcohol reaches to $81 \mathrm{~mol} \%$, the conversion of hydrogen peroxide is $97 \mathrm{~mol} \%$.

The advantages of using high methanol concentration can be the result of the hydrophilic character of the catalyst. In accordance with the reaction mechanism, methanol plays a key role in the formation of the five-membered active adducts at 


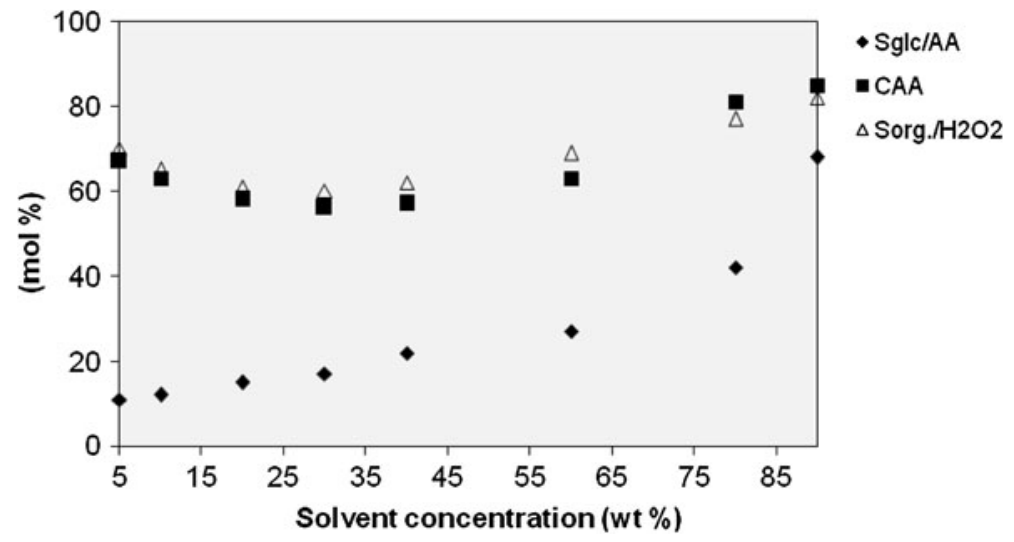

Fig. 4 The influence of solvent concentration (methanol) on the allyl alcohol epoxidation over Ti-MWW catalyst; temperature $20{ }^{\circ} \mathrm{C}, \mathrm{AA} / \mathrm{H}_{2} \mathrm{O}_{2}=1: 1$ molar ratio, Ti-MWW concentration $2 \mathrm{wt} \%$, reaction time $3 \mathrm{~h}$, intensity of stirring $500 \mathrm{rpm}$

Table 3 The influence of solvent concentration on the selectivity of transformation to by-products in the epoxidation of allyl alcohol over Ti-MWW catalyst

\begin{tabular}{|c|c|c|c|c|c|}
\hline $\begin{array}{l}\text { Methanol } \\
\text { concentration } \\
\text { (wt } \%)\end{array}$ & $\begin{array}{l}\text { Glycerol } \\
\text { (GLYC) } \\
S_{\text {Glyc/AA }} \\
(\mathrm{mol} \%)\end{array}$ & $\begin{array}{l}\text { Bis(allyl) } \\
\text { ether (EBA) } \\
S_{\text {EBA/AA }} \\
(\text { mol\%) }\end{array}$ & $\begin{array}{l}\text { Allyl-glycidyl } \\
\text { ether (EAG) } \\
S_{\text {EAG/AA }}(\mathrm{mol} \%)\end{array}$ & $\begin{array}{l}\text { Acrolein } \\
\text { (ACR) } \\
S_{\text {ACR/AA }} \\
(\mathrm{mol} \%)\end{array}$ & $\begin{array}{l}\text { 3-Allyloxy-1,2- } \\
\text { propanediol (3A2PD) } \\
S_{3 \mathrm{~A} 12 \mathrm{PD} / \mathrm{AA}}(\mathrm{mol} \%)\end{array}$ \\
\hline 5 & 81 & 2 & 2 & 1 & 3 \\
\hline 10 & 78 & 3 & 3 & 0 & 4 \\
\hline 20 & 75 & 3 & 3 & 0 & 4 \\
\hline 30 & 70 & 4 & 4 & 0 & 5 \\
\hline 40 & 62 & 5 & 5 & 0 & 6 \\
\hline 60 & 54 & 6 & 6 & 0 & 7 \\
\hline 80 & 28 & 9 & 10 & 0 & 11 \\
\hline 90 & 23 & 5 & 4 & 0 & 0 \\
\hline
\end{tabular}

the positions bound with titanium built into the structure of the catalyst. The high methanol concentration accelerates the rate of epoxidation and limits the formation of by-products. The results confirm that the mechanism of epoxidation proposed in the literature [15] is correct.

The influence of catalyst concentration

The influence of catalyst concentration in the epoxidation of allyl alcohol over TiMWW catalyst was presented in our previous work [13]. The optimal catalyst concentration at this stage of the process is $2 \mathrm{wt} \%$. 
The influence of reaction time

The influence of the reaction time on the course of epoxidation was examined in the range of 5-300 min (Fig. 5). Other parameters corresponded to the values previously established as optimal.

The studies showed (Fig. 5) that time has a very significant effect on the way of changing values of the functions describing the process only in range of $5 \mathrm{~min}$ to $20 \mathrm{~min}$. After $20 \mathrm{~min}$ or longer time of the reaction, they maintain a constant value or they undergo little changes. The selectivity of transformation to glycidol after $20 \mathrm{~min}$ reaches $47 \mathrm{~mol} \%$ and practically does not undergo any changes to $300 \mathrm{~min}$. The selectivity of transformation to organic compounds in relation to hydrogen peroxide consumed reaches the highest value $(98 \mathrm{~mol} \%$ ) after $180 \mathrm{~min}$ and does not undergo any changes during longer time of reaction. The conversion of $\mathrm{H}_{2} \mathrm{O}_{2}$ as a function of time exhibits similar changes. A slight increase of the conversion of allyl alcohol marks from $10 \mathrm{~min}$ to $180 \mathrm{~min}$ (from about $71 \mathrm{~mol} \%$ to $82 \mathrm{~mol} \%$ ) and for longer reaction this function does not change. The main quantity of glycidol is formed after $180 \mathrm{~min}$, but the maximum amount is received after $180 \mathrm{~min}$. The selectivity of transformation to by-products, over a time period of 15-300 min are on a similar level, and the selectivities of by-products amount to: glycerol 20-29 mol\%, bis(allyl) ether 8-10 mol\%, allyl-glycidyl ether 8-11 mol\%, 3-allyloxy-1,2-propanediol 8-10 mol\% (Table 4).

Therefore $60 \mathrm{~min}$ time of reaction is the most beneficial to carry out the epoxydation of allyl alcohol over Ti-MWW catalyst taking into consideration the values of remaining parameters.

The influence of intensity of stirring

The influence of stirring speed was investigated in the range from 0 to $500 \mathrm{rpm}$ and the course of functions of conversion and selectivity is presented in Fig. 6 and

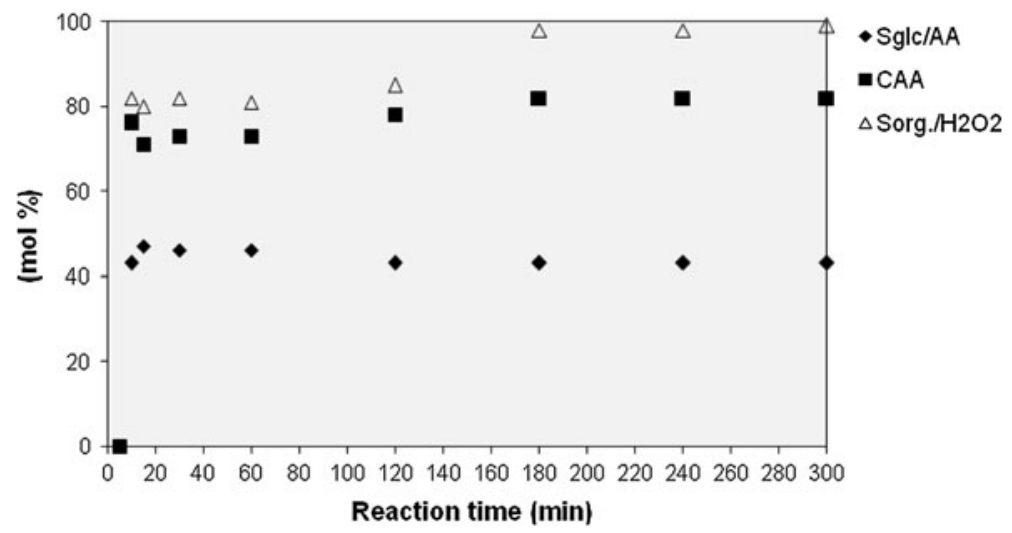

Fig. 5 The influence of the reaction time on the allyl alcohol epoxidation over Ti-MWW catalyst; temperature $20{ }^{\circ} \mathrm{C}, \mathrm{AA} / \mathrm{H}_{2} \mathrm{O}_{2}=1: 1$ molar ratio, methanol concentration $80 \mathrm{wt} \%$, Ti-MWW concentration $2 \mathrm{wt} \%$, intensity of stirring $500 \mathrm{rpm}$ 
Table 4 The influence of reaction time on the selectivity of transformation to by-products in the epoxidation of allyl alcohol over Ti-MWW catalyst

\begin{tabular}{|c|c|c|c|c|c|}
\hline $\begin{array}{l}\text { Reaction } \\
\text { time (min) }\end{array}$ & $\begin{array}{l}\text { Glycerol } \\
\text { (GLYC) } \\
S_{\text {Glyc/AA }} \\
(\mathrm{mol} \%)\end{array}$ & $\begin{array}{l}\text { Bis(allyl) ether } \\
\text { (EBA) } \\
S_{\mathrm{EBA} / \mathrm{AA}} \\
(\mathrm{mol} \%)\end{array}$ & $\begin{array}{l}\text { Allyl-glycidyl } \\
\text { ether (EAG) } \\
S_{\text {EAG/AA }}(\mathrm{mol} \%)\end{array}$ & $\begin{array}{l}\text { Acrolein } \\
\text { (ACR) } \\
S_{\mathrm{ACR} / \mathrm{AA}} \\
(\mathrm{mol} \%)\end{array}$ & $\begin{array}{l}\text { 3-Allyloxy-1,2- } \\
\text { propanediol (3A2PD) } \\
S_{3 \mathrm{~A} 12 \mathrm{PD} / \mathrm{AA}}(\mathrm{mol} \%)\end{array}$ \\
\hline 5 & 0 & 0 & 0 & 0 & 0 \\
\hline 10 & 26 & 9 & 10 & 0 & 12 \\
\hline 15 & 21 & 10 & 11 & 0 & 11 \\
\hline 30 & 21 & 10 & 11 & 0 & 12 \\
\hline 60 & 21 & 10 & 11 & 0 & 12 \\
\hline 120 & 24 & 10 & 11 & 0 & 12 \\
\hline 180 & 27 & 9 & 10 & 0 & 11 \\
\hline 240 & 27 & 9 & 10 & 0 & 11 \\
\hline 300 & 27 & 9 & 10 & 0 & 11 \\
\hline
\end{tabular}

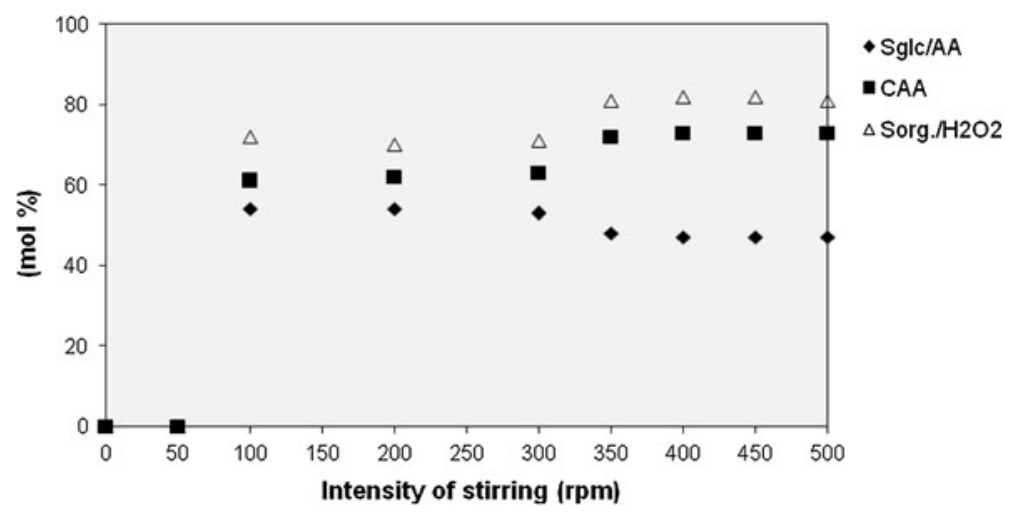

Fig. 6 The influence of stirring intensity on the allyl alcohol epoxidation over Ti-MWW catalyst; temperature $20{ }^{\circ} \mathrm{C}, \mathrm{AA} / \mathrm{H}_{2} \mathrm{O}_{2}=1: 1$ molar ratio, methanol concentration $90 \mathrm{wt} \%$, Ti-MWW concentration $2 \mathrm{wt} \%$, reaction time $60 \mathrm{~min}$

Table 5. The constant parameters in this series studies were as follows: temperature $20{ }^{\circ} \mathrm{C}, \mathrm{AA} / \mathrm{H}_{2} \mathrm{O}_{2}=1: 1$ molar ratio, methanol concentration $80 \mathrm{wt} \%$, catalyst concentration $2 \mathrm{wt} \%$ and time $60 \mathrm{~min}$.

The reaction does not proceed when the intensity of stirring is in the range $0-50 \mathrm{rpm}$. The value of function of the selectivity of transformation to glycidol increases to $54 \mathrm{~mol} \%$ at a stirring intensity of $100-300 \mathrm{rpm}$. In the range of $350-500 \mathrm{rpm}$, a small decrease of value is observed. It results from more intense hydration of glycidol to glycerol in the consecutive reaction. The conversion of AA and the selectivity of transformation to organic compounds in relation to hydrogen peroxide consumed exhibit similar tendencies changes. In the range 350-500 rpm, the conversion of AA is constant and achieves the maximum value $73 \mathrm{~mol} \%$. At this 
Table 5 The influence of stirring intensity on the selectivity of transformation to by-products in the epoxidation of allyl alcohol over Ti-MWW catalyst

\begin{tabular}{|c|c|c|c|c|c|}
\hline \\
\hline \multicolumn{6}{|c|}{$\begin{array}{llllll}\text { Selectivity of transformation to by-products in the epoxidation of allyl alcohol } S_{\text {product/AA }}(\mathrm{mol} \%) \\
\text { Intensity of } & \text { Glycerol } & \text { Bis(allyl) } & \text { Allyl-glycidyl } & \text { Acrolein } & \text { 3-Alliloxy-1,2- } \\
\text { stirring (RPM) } & \text { (GLYC) } & \text { ether (EBA) } & \text { ether (EAG) } & \text { (ACR) } & \text { propanediol (3A2PD) }\end{array}$} \\
\hline \multicolumn{6}{|c|}{$\begin{array}{llllll}\text { Intensity of } & \text { Glycerol } & \text { Bis(allyl) } & \text { Allyl-glycidyl } & \text { Acrolein } & \text { 3-Alliloxy-1,2- } \\
\text { stirring (RPM) } & \text { (GLYC) } & \text { ether (EBA) } & \text { ether (EAG) } & (\text { ACR) } & \text { propanediol (3A2PD) } \\
& S_{\text {Glyc/AA }} & S_{\text {EBAAA }} & S_{\text {EAG/AA }}(\mathrm{mol} \%) & S_{\text {ACR/AA }} & S_{\text {3A12PD/AA }}(\text { mol\%) } \\
& (\text { mol\%) } & (\text { mol\%) } & & (\text { mol\%) } & \end{array}$} \\
\hline 100 & 8 & 12 & 12 & 0 & 14 \\
\hline 200 & 8 & 12 & 12 & 0 & 14 \\
\hline 300 & 10 & 11 & 12 & 0 & 14 \\
\hline 350 & 19 & 10 & 11 & 0 & 12 \\
\hline 400 & 21 & 10 & 11 & 0 & 11 \\
\hline 450 & 21 & 10 & 11 & 0 & 11 \\
\hline 500 & 21 & 10 & 11 & 0 & 11 \\
\hline
\end{tabular}

stirring speed, the selectivity of transformation to organic compounds also achieves the maximum value equal to $80 \mathrm{~mol} \%$. The increase in stirring speed causes an increase of the selectivity of transformation to organic compounds in relation to $\mathrm{H}_{2} \mathrm{O}_{2}$ consumed, especially in the range $50-100 \mathrm{rpm}$. At constant conversion of $\mathrm{H}_{2} \mathrm{O}_{2}$, this means the growth of the total amount of organic compounds. At the highest value of stirring speed the value of conversion of AA is $73 \%$ mol. The increase of stirring speed causes increase the conversion of AA and the selectivity of transformation to organic compounds. At constant conversion of $\mathrm{H}_{2} \mathrm{O}_{2}$ that means increase of overall amount of forming organic compounds.

Initially, during a low intensity of stirring (50-100 rpm) the reaction proceeds in a dynamic range. The slowest stage, which limits the rate of epoxidation, is the transport of $\mathrm{H}_{2} \mathrm{O}_{2}$ and the AA to active centre of catalyst. In the range of stirring intensity 100-300 rpm, only $16 \%$ of the obtained glycidol undergoes hydration to glycerol (selectivity of glycidol about $54 \mathrm{~mol} \%$, selectivity of glycerol about $8-10 \mathrm{~mol} \%$ ). In the range of stirring intensity $300-350 \mathrm{rpm}$, the selectivity of glycerol increases to $19-20 \mathrm{~mol} \%$, and the selectivity of glycidol decreases to $48 \mathrm{~mol} \%-28 \%$, glycidol undergoes hydration to glycerol. Simultaneously, the increase in values of conversion of AA and selectivity of transformation to organic compounds in relation to hydrogen peroxide consumed is observed. Above the stirring intensity of $350 \mathrm{rpm}$, the main functions describing the process do not change. The stirring speed, with steady remaining parameters unchanged, should be at least $350 \mathrm{rpm}$.

\section{Conclusions}

The process of allyl alcohol (AA) epoxidation over the titanium silicalite catalyst Ti-MWW, under atmospheric pressure has been found to be the most effective when is conducted at temperature of $20{ }^{\circ} \mathrm{C}$, the molar ratio of $\mathrm{AA} / \mathrm{H}_{2} \mathrm{O}_{2}=1: 1$, methanol concentration of $80 \mathrm{wt} \%$, the catalyst concentration of $2 \mathrm{wt} \%$, in the time of $60 \mathrm{~min}$ 
and with the stirring intensity over $500 \mathrm{rpm}$. Under these conditions, the selectivity of transformation to glycidol in relation to AA consumed is $47 \mathrm{~mol} \%$, the AA conversion reaches $73 \mathrm{~mol} \%$ and the selectivity of transformation to organic compounds in relation to hydrogen peroxide consumed is $81 \mathrm{~mol} \%$. The studies also showed that the temperature and catalyst concentration [13] do not have a significant impact on the selectivity of transformation to glycidol. On the other hand, the rest of the technological parameters changed significantly values this main function of the process: the molar ratio of $\mathrm{AA} / \mathrm{H}_{2} \mathrm{O}_{2}$ in the range of 1:1-5:1 (from 20 to $41 \mathrm{~mol} \%$ ), methanol concentration in the range of 5-90 wt\% (from 10 to $60 \mathrm{~mol} \%$ ), the reaction time in the range of 5-20 min (from 0 to $47 \mathrm{~mol} \%$ ) and intensity of stirring in the range of 100-300 rpm (from 0 to $54 \mathrm{~mol} \%$ ).

Open Access This article is distributed under the terms of the Creative Commons Attribution Noncommercial License which permits any noncommercial use, distribution, and reproduction in any medium, provided the original author(s) and source are credited.

\section{References}

1. Baerlocher Ch, Meier W, Olson D (2001) Atlas of zeolite framework types. 5th revised edition. Elsevier, Amsterdam

2. Fan W, Wu P, Namba S, Tatsumi T (2006) Synthesis and catalytic properties of a new titanosilicate molecular sieve with the structure analogius to MWW-type lamellar precursor. J Catal 243:183-191

3. Wu P, Tatsumi T, Komatu T, Yashima T (2002) A novel Titanosilicate with MWW structure: II catalytic properties in the selective oxidation of alkenes. J Catal 202:245-255

4. Wu P, Tatsumi T (2002) Preparation of B-free Ti-MWW through reversible structural conversion. Chem Commun 1026-1027

5. Degnan T (2003) The implications of the fundamentals of shape selectivity for the development of catalysts for the petroleum and petrochemical industries. J Catal 216:32-46

6. Wu P, Liu Y, He M, Tatsumi T (2004) A novel Titanosilicate with MWW structure: catalytic properties in selective epoxidation of Diallyl ether with hydrogen peroxide. J Catal 228:183-191

7. Song F, Liu Y, Wu H, He M (2006) A novel Titanosilicate with MWW structure: highly effective liquid-phase ammoximation of cyclohexanone. J Catal 237:359-367

8. Wróblewska A, Rzepkowska M, Milchert E (2005) Optimization of technological parameters of epoxidation of allyl alcohol by hydrogen peroxide over Ti-Beta catalyst. Appl Catal A Gen 294:244-255

9. Kłopotek A, Kłopotek B (1990) 2,3-Epoksypropanol-1-ol jako substrat środków powierzchniowoczynnych. Przem Chem 69:248-251

10. Von Wolfgang M, Klemann A, Schreyer G (1975) Glycid-Herstellung and Eigenschaften. Chemiker-Zeitung 1:19-26

11. Wróblewska A, Milchert E (2003) Bezodpadowe epoksyowanie alkoholu allilowego w obecności katalizatorów tytanowo-silikalitowych. Przem Chem 82:1063-1065

12. Wu P, Tatsumi T, Komatsu T, Yashima T (2001) A novel titanosilicate with MWW structure. I. Hydrothermal synthesis, elimination of extraframework titanium, and characterizations. J Phys Chem B 105:2897-2905

13. Wróblewska A, Fajdek A, Milchert E, Grzmil B (2010) The Ti-MWW catalyst—its characteristic and catalytic properties in the epoxidation of allyl alcohol by hydrogen peroxide. Pol J Chem Technol 12:29-34

14. Davies L, McMorn P, Bethell D, Bulman P, King F, Hancock F, Hutchings G (2000) By-product formation causes leaching of Ti from the redox molecular sieve TS-1. Chem Commun 1807-1808

15. Adam W, Corma A, Reddy T, Renz M (1997) Diastereoselective catalytic epoxidation of chirac allylic alcohols by the TS-1 and Ti-Beta zeolites: evidence for hydrogen-bonded, peroxy-type loaded complex as oxidizing species. J Org Chem 62:3631-3637 